\title{
"We Cannot Shoo These Men to Another Place": \\ The On to Ottawa Trek in Toronto and Ottawa
}

\section{Steven R. Hewitt}

\begin{abstract}
This year is the sixtieth anniversary of the On to Ottawa Trek. The original Trek started in Vancouver as over a thousand unemployed men attempted to reach Ottawa by rail to express their discontent with the policies of the Bennett government. Their journey ended in Regina when a police-provoked riot led to their dispersal. Major works on the subject have not recognized that parallel treks occurred in Manitoba and Ontario from June to August 1935. "We Cannot Shoo These Men to Another Place" explores trek evenes in Toronto and Ottawa and discovers that while the trek itself was a failure, it did reveal the anti-Communist paranoia of both the political right and left and the Canadian state.
\end{abstract}

While it was normal for people to busde about the Vancouver rail station, there was a difference on the evening of 3 June 1935. Several hundred men, wearied by the seemingly endless Depression and the hopelessness of their lives, climbed on to the roofs of the rail cars and set off for Ottawa. On strike from British Columbia relief camps, they had decided to take their anger and grievances directly to those deemed responsible for creating the environment of despair: the Conservative government of Richard Bedford Bennett. The On to Otcawa Trek, ${ }^{1}$ as it was to become known, gained new recruits as it progressed east, especially in Calgary where an enthusiastic welcome greeted the tired men. ${ }^{2}$ Eventually on 12 June, the Royal Canadian Mounted Police (RCMP), acting under the orders of the federal government, halted the Trek in Regina. A fumbled police attempt to arrest the Trek's leadership on Dominion Day 1935 resulted in a riot and the death of one policeman, injuries to dozens of Trekkers and policemen, and thousands of dollars of damage to downtown Regina. The clash in 
Regina resulted in the dispersal of the BC Trekkers a few days later. ${ }^{3}$

The grievances which fueled the BC Trek emanated directly from the relief camp system run by the Department of National Defence. The camps were a desperate attempt by the Conservative government to deal with the perceived threat to civil order posed by several thousand single, homeless, unemployed men. ${ }^{4}$ In 1932 Major-General Andrew McNaughton put forward the relief camp scheme as a means of removing from urban centres these potential recruits for Communist agicators. Hence most of the military-administered camps were placed in remore areas across Canada. Since security, rather than the welfare of the men was the primary concern, it was inevicable that a sense of discontent would fester among those in the relief camps. The men's unhappiness was heightened by the manual labour they forcibly performed for a paltry twenty cents a day.

With the unemployed now concentrated in the camps, the work of agitators and organizers was that much easier.s Strikes and other disturbances became commonplace in the system. ${ }^{6}$ The discontent culminated in April 1935 when several thousand residents of the camps went on strike in British Columbia. Many of these same men rode the rail cars in June in an attempt to reach Ottawa.?

The BC Trek, with its violent conclusion in Regina, has traditionally been viewed as a regional phenomenon. The impact of the On to Ottawa Trek, however, extended far beyond Regina. In Ottawa on 22 June 1935, after two failed meetings with Prime Minister Bennett and his cabinet, BC Trek leaders and a collection of central Canadian Communists, labour leaders, and Hunger March organizers issued a joint call for a national trek to the capital. ${ }^{8}$ The literature informs us of the fate of the Trekkers from British Columbia. What happened beyond Regina, however, remains little examined.

Two approaches dominate the historiography of the On to Ottawa Trek east of Regina. Either ill informed assumptions are made about the march or it is completely 
ignored. In the former category are most of the specific works on the Trek: Victor Howard's "We were the salt of the earth!, "Lorne A. Brown's When Freedom Was Lost, and Ronald Liversedge's Recollections of the On to Ottawa Trek, offer scant decail of the impact of such a call or, for that matter, the impact of the Trek itself in Ontario, Ottawa's home province. ${ }^{9}$ Howard offers one paragraph on the arrival of a group of trekkers in Ottawa. ${ }^{10}$ Brown's account is contradictory as he notes on one page that "[d]uring July and August 1935 the issues surrounding the Trek and the Regina Rior were kept before the public by trade unions and civil liberties associations," while on another he asserts: "There were unsuccessful attempts to organize another Trek from points east of Regina ... . However, they did not receive much national attention and their expedition was generally looked upon as anti-climatic." "He never explains why this was the case. Liversedge ignores Trek-related events in Ontario as does Jan Angus's Canadian Bolsheviks which compounds the lack of detail on events east of Regina with inaccurate statements, such as: "[Despite the fact that the Trek has] achieved semi-legendary status for labour historians-few seem aware that ... the On-toOttawa Trekkers ... never got within 2,000 miles of Ottawa."12

For the Trek to have succeeded it would have had to pass through Canada's most populated province in the summer of 1935. And although the Western-born movement failed to find a substantial following in two of Ontario's most important cities, Toronto and Ottawa, it did, nevertheless, have a significant impact on the municipal politics of these cities and upon the provincial politics of Ontario during this period. As well, the Trek demonstrated the continuum of anti-communist paranoia that existed in Toronto throughout the 1930s and it brought into public focus the strong enmity between the Cooperative Commonwealth Federation (CCF) and the Communist Party of Canada (CPC) in an election year. The Trek's significance extended beyond Regina but perhaps not in the way organizers of the march would have intended. 
Based on Toronto's record in dealing with dissent over the previous decade, the Trekkers could not have expected a warm welcome from civic authorities. The city was not friendly towards any form of political dissent. The city police, under the leadership of Brigadier-General Dennis Draper, regularly employed violence to disrupt displays of peaceful protest. ${ }^{13}$ Historian Michiel Horn has written extensively about the hostility directed at those deemed by the authorities to be radicals. The most ludicrous extreme was represented in a by-law which forbade public speeches in any language other than English. ${ }^{14}$ This and other measures provoked an outcry from academics at the University of Toronto as revealed by sixty-eight names appearing on a letter that condemned the attacks upon "free public expression of opinions, however unpopular or erroneous." ${ }^{\text {15 }}$ Nevertheless, radicalism was associated with foreigners as the dominant British mentality went into overdrive; it reflected conflicting values: platitudes toward liberties, but also an emphasis on respect and obedience of authority. ${ }^{16}$

Superficially, at least, the Toronto of 1935 appeared different from only a few years earlier. The impetus for change was both social and political. The ravaging effects of the Great Depression had created a civic and provincial populace more willing to try less traditional electoral alternatives. The first major change occurred in 1934 when the Liberal Party under Mitchell Hepburn won the provincial election. The man from St. Thomas described himself as "well to the left where even Liberals will not follow. ${ }^{\text {"1 }}$ An even greater change in the Toronto political environment occurred on 1 January 1935 when 42 percent of voters elected the CCF candidate, James "Jimmie" Simpson, mayor, a move which the Toronto Globe described as not doing "justice to the common sense of Toronto."18 Simpson had a long record of political and labour activism, including his election in 1914 to Toronto's Board of Control as a member of the Social Democratic Party of Canada. ${ }^{19}$ 
Hunger marches, a phenomenon of the 1930 s, would seem to have prepared Toronto for an event such as the Trek. These marches, of which the Trek was a variation, occurred regularly in 1930s Ontario. These movements, largely organized and led by Communists, brought unemployed Ontarians to Toronto to protest the policies of the provincial government. Such an event was underway in June of 1935 while the On to Ottawa Trek was beginning in British Columbia. Initially there was no connection between the two events, but the Ontario Hunger March leadership began to threaten their own trek to Ottawa if the federal government rebuffed the demands of the BC men. ${ }^{20}$ The Ontario march leaders also requested that they be included in the delegation that would meet with Bennett. Eventually a delegation of four would do just that, although their meeting with the prime minister occurred after that of the BC Trekkers. Afterwards, the two delegations held a joint conference which called for a Canada-wide trek to Ottawa."

Activities directed toward a Toronto-based trek were limited in June because events in Regina held everyone's attention. The actions that did occur in Toronto were aimed at aiding the cause of the BC Trekkers. Wires sent to Regina asked that six Trekkers be sent to Toronto to generate interest in the event (eventually one would make the journey). Plans also included a mass meeting on behalf of the On to Ottawa Trek at Maple Leaf Gardens in July. Various unions and churches, the CCF, and other sympathetic groups received a request for their support. Finally, offices to register potential trekkers and radio advertising to spread the word were to be acquired. ${ }^{22} \mathrm{On}$ 28 June, a telegram from BC Trek leader Arthur "Slim" Evans arrived; Evans, still stranded in Regina, suggested that a "TREK ON A NATIONAL SCALE WOULD ... RELIEVE THE PRESSURE HERE." ${ }^{23}$ The following day in Toronto, the Communist-affiliated Workers' Unity League and the National Unemployment Council responded to Evans by calling for treks to Ottawa. The first Ontario treks were 
expected to begin on 6 July while the Toronto leg was scheduled to leave on 13 July. A mass rally in support of the Trek was scheduled for 5 July. ${ }^{24}$

The tension in Regina dominated the trek situation in Toronto. Public discussion in Ontario's capical revolved around the federal government's policy towards the BC Trekkers. The Toronto East Presbytery of the United Church of Canada cautioned each side to avoid violence. Various other clergy weighed in on one side or the other in the debate. ${ }^{25}$ The CCF in the Toronto area also became increasingly active in events surrounding the On to Ottawa Trek. Graham Spry, head of the party's Ontario wing, warned in a private letter of the danger to the $\mathrm{CCF}$ if it stayed on the sidelines:

I hope, whatever the risks to the $\mathrm{CCF}$, that we can get fully behind the march. To be neutral, it seems to me, would be a disaster, in an issue like this, it seems to me, there is no neutrality; cither we back the marchers or we are forced into the position of appearing to back Mr. Bennett and his minions. ${ }^{26}$

Members of the CCF were encouraged to join the coalition of groups supporting the On to Ottawa Trek. This was in line with the position adopted by the Communist International in 1935 at Joseph Stalin's behest, for a "united front" approach against fascism. Earlier in the 1930s, Communists had viewed other parties of the left as their primary enemies, labelling them as "social fascists" and enemies of the working class. In Canada the CPC applied its own appellation of "Labour Fascist" to prominent social democrats such as J.S. Woodsworth. With the growing threat of Nazi Germany, Stalin, through the Comintern, called for Communist parties to seek "united fronts" of the left and all "democratic forces" in the battle against the far right. Within the CCF, in turn, Communist appeals for left-wing unity would produce bitter divisions. The CCF in this period generally regarded favourably the economic and social policies of the Soviet Union, according to its perception of them. But it deplored 
the authoritarianism of the Soviet state and regarded the Canadian Communists as advocates of both political violence and one-party rule. Those on the left within the CCF, however, responded positively to Communist calls for unity while colleagues on the right reacted with doubt and a belief that cooperating too closely would lead to the political elimination of social democrats. ${ }^{27}$

The CCF did involve itself in the Trek movement, albeit somewhat halfheartedly, choosing to emphasize the importance of protecting civil liberties, a cause not traditionally associated with the Communist Party. At a 5,000 strong rally in East York on 20 June party leader, J.S. Woodsworth, attacked the Bennett government's handling of the Trek. The same day, three separate Cooperative Commonwealth Youth Movement (CCYM) rallies were held in Toronto to protest the treatment of the $\mathrm{BC}$ Trekkers. ${ }^{28}$ Ironically, a CCF rally occurred on 1 July, only a few hours before violence would erupt in Regina. Mayor Simpson, the guest speaker, appealing to the still dominant British mencality of the elite, described the halting of the Trekkers as "unconstitutional and thoroughly un-British. It has been the traditional right of a British subject to carry his appeal for justice even to the foot of the Throne, but Mr. Bennett has taken it upon himself to abolish that right."29

The Regina Riot and the collapse of the British Columbia Trek placed a new emphasis upon events in Toronto. Initially the federal government's involvement in the riot received widespread condemnation. Simpson's comments at a 2 July CCF meeting were typical: "The pitiable sight was seen this week because some men had dared to ask the government for their rights. I am proud to uphold British institutions; the right of assembly; the right of expression. ${ }^{30} \mathrm{~A}$ more vitriolic condemnation of the Bennett government emanated from Ontario's Attorney-General, Arthur Roebuck. He charged that the federal government had deliberately allowed the Trek to begin and travel as far as it did because the Conservatives sought political advantage from the disorder the march appeared to represent. 
By portraying the march as Communist inspired and led, Roebuck argued, Bennett could then justify a crackdown while declaring the need for a strong government to deal with such insurrections - and all of this just prior to a fall election. He noted that the Hepburn government had dealt peacefully with three separate hunger marches. ${ }^{31}$ Premier Hepburn wholeheartedly endorsed his colleague's statement. In addition, he commented on the proposal to begin an Ontario version of the On to Ottawa Trek:

We want no interference in this province with hunger marchers. If they conduct themselves in an orderly manner they have a perfect right to march to Ottawa and lay their case before the man who five years ago planned to end unemployment. ... Bennett can't fool anybody anywhere anymore. He'll get no sympathy from us if he tries his iron-heel tactics in ... Ontario. ${ }^{32}$

The only specific public response from ordinary Torontonians to the crushing of the On to Ottawa Trek in Regina occurred when a Globe reporter took to the streets to conduct impromptu interviews. The underlying message in the seventeen different male responses was a disapproval of the use of violence by both the government and the Trekkers. ${ }^{33}$

Events in Saskatchewan on Dominion Day did initiate an interest in the On to Ottawa Trek that undoubtedly would not have existed had the BC Trekkers quietly dispersed on their own. Organized labour was one group that went public in its denunciation of the federal government's handling of the Trek. The response, not surprisingly, was still conservative in nature. The Toronto District Labour Council condemned the Bennett government's "policy of repression," but rejected an offer to participate in a mass rally at Maple Leaf Gardens because the Council wanted no association with Communists. ${ }^{34}$ Several telegrams, petitions, and letters appeared in the prime minister's office from various Toronto unions. All of these organizations announced their outrage at the use of force by the federal government against, to use the words of 
one letter, "the peaceful demonstration of the unemployed marchers. "35 The reaction of labour, however, did not go beyond words. Indeed, the Toronto District Labour Council's message to its members specifically cautioned them against any extreme action. ${ }^{36}$

A more conservative mentality was also beginning to reassert itself among elements of Toronto's political elite, including Mayor Simpson. They worried about the radical tinge in the Oncario trek movement. Simpson, who had publicly attacked the Bennett government's treatment of the Trekkers, slowly began to shift his position. After Bennett publicly linked communism with the On to Ottawa Trek, the mayor chose to emphasize "that we are not going to have any truck or trade with Communists. ... [T] he [CCF] and the Labour Congress of Canada will not countenance any Communist uprising." $\mathrm{He}$ added, however, that certain freedoms had to be allowed under the Magna Carta. ${ }^{37}$ Soon Simpson would not even bother to add the democratic addendum to his anti-Communist rhetoric.

During this period, organization for an Ontario trek to Ottawa continued. On 6 July, the Ontario Workers' Federation, an organization previously involved in hunger marches, claimed that 6,000 registration cards had been distributed throughout the province; 2,000 marchers were expected to leave for Ottawa from Toronto on 11 or 13 July ${ }^{38}$ Before that, however, rallies to raise funds and the public profile of the march were required. One such event occurred at Maple Leaf Gardens on 5 July; it represented the high-water mark of Toronto's interest in the On to Otcawa Trek. A few thousand people gathered to hear a BC Trekker and a Regina clergyman speak. Several prominent left-wing figures, including Graham Spry; Sam Carr, assistant secreary of the Communist Party; Tom McEwen, a veteran Communist and head of the Workers' Unity League; the Reverend Salem Bland; and A.E. Smith, leader of the Canadian Labour Defence League (CLDI), shared the stage. ${ }^{39}$ Several other radical labour and political organizations sent delegates. Mayor Simpson, however, elected not to attend. 
During the rally the fragile unity of the rally's participants, especially bewteen traditional enemies, such as the CCr and CPC, appeared evident to all. Sam Carr noted that it required "the blood of members of [the working] class to get the CCF and other groups to attend with us." 40

It was an easy task to criticize the Bennett government over its handling of the Trek. With preparations underway for a new Ontario-based trek, however, many of the federal government's critics had the opportunity to demonstrate whether their criticism was based on conviction or political expediency. A speaker at the 5 July rally had argued that the proper course of action "to combat Bennett's fascist tactics is to go to Ottawa."41 Such a movement-one estimate placed the size of the contingent at 7,000 to 8,000 strong-required support. And while the leadership of the Ontario trek was largely Communist, "the great majority of us," an anonymous trekker wrote in the Globe, "are just out of school, and we want work ... [or] some means by which we can maintain our self-respect." 42

In the meantime, the trek-support movement began to unravel. On 9 July, the RCMP arrested Matt Shaw, the BC Trekker who addressed the Maple Leaf Gardens rally. This move provoked an immediate outcry. The CCF, which organized street demonstrations, led the fight against Shaw's seizure, promising to find legal counsel for the new prisoner. Handbills announced an 11 July mass gathering at Queen's Park to protest the arrest. The strength of the reaction generated by the arrest, however, was not sufficient to prevent the public disintegration of the CCFCommunist coalition. Before a crowd of 3,000, the Queen's Park meeting rapidly degenerated into a display of base partisanship. Communist A.E. Smith, head of the CLDL, used his speech to argue that his organization was not Communist-controlled, for which he received loud applause. Graham Spry, perhaps also remembering Carr's factious jab at the Maple Leaf Gardens rally, responded with the prediction that Tim Buck would lose in the upcoming federal election to the CCF candidate, A.A. Heaps. After 
being roundly booed he added: "I didn't start this, just keep that in mind. If you introduce is you can expect to be replied to. If there are any more boos, get it over with, for I wish to calk about Matt Shaw. ${ }^{\text {n3 }}$ But the damage had already been done. The CCF involvement in the trek movement effectively ended. By the time the trek from Toronto began, absent from its official demands was any call for a repeal of Section $\mathbf{9 8}$ of the Criminal Code, a civil liberties cause identified with the CCF. ${ }^{44}$ Having been rebuffed by the Ontario trek movement, the CCF leadership responded by simply ignoring the march to Ottawa. The New Commonwealth, edited by Spry, did not carry a single story about the Ontario leg of the trek.

Another member of the CCF supplied an even more visible sign that the party's partnership with the Communist Party had ended: Mayor Jimmie Simpson was now the Toronto trekkers' main enemy. The man who had defended the right of citizens to take their grievances directly to the seat of government now repudiated both the Communist involvement in the trek and the trek itself:

In such trying times 1 do not feel that such spectacular methods are best. [The trekkers] should send their representatives to the seat of authority to make representation on their behalf.

I can see that those responsible for the march are determined to override obstruction of any kind. They are challenging law and order and constitured authority. To be weak and vacillating means encouraging a certain type of individual to revolutionary methods. ${ }^{45}$

Accordingly, the mayor forbade tag days (a method of raising money by the selling of tags to wear on one's clothing) for the trekkers even though he did not have the power to do so, and announced that anyone entering Toronto to participate in the trek would not be allowed to sleep in the city's parks. Despite Simpson's threats, the trekkers proceeded with their search for financial assistance. ${ }^{46}$ Clearly frustrated by the trekkers' skirting of authority, Simpson intensified his rhetoric on 15 July when he 
announced that they would not be allowed to parade without a permit. Earlier in the day, a group of trekkers in formation marched past city hall in an apparent attempt to snub the onlooking mayor, prompting the warning that if any more unauthorized parades occurred the participants would "be regarded as revolutionaries and treated as such." conjunction with this announcement, Mayor Simpson ordered Chief of Police Draper to cooperate actively with the Ontario Provincial Police (OPP) and railway police to prevent trouble, especially any attempt to use the trains for transportation to Ottawa. ${ }^{48}$ In a final blow to the trekkers, Toronto City Council voted eleven to four against even listening to a trek delegation requesting food and accommodation. Simpson, who did not vote on the motion, stiffly observed that "law and order" would be maintained. 49 A day later, the police arrested fourteen caggers; five were charged with vagrancy and the remainder with illegal solicitation of funds. ${ }^{30}$

The Hepburn government was also gradually moving toward an anti-trek policy. Its response to the arrest of Matt Shaw was surprisingly meek. The RCMP had officially requested that an Ontario court authorize the removal of the Trekker to Saskatchewan. Hepburn publicly announced on 15 July that he would not consent to such an action and then without explanation quietly reversed his government's

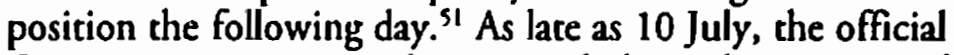
Ontario government policy toward the trek was one of strict neutrality. Then on 16 July, Hepburn suddenly announced a much more restrictive policy towards the Ontario trek. ${ }^{52}$ An attempt was made to justify the unexpected shift in the government's position:

[The trekkers] have lost public sympathy-that is, if I interpret public opinion. They call this thing the workers' hunger march, but the people are beginning to see through it. They aren't workers, for when there are jobs on the farms they won't take them. They aren't hungry because mayors and reeves have assured me that there isn't a single case of malnutrition in the province. Now we find they don't even want to march, they want to ride in trucks. ${ }^{33}$ 
The previous policy emanated from a belief that the trek would dissolve of its own accord; Hepburn had repeatedly emphasized the uselessness of the exercise and the lengthy distance to Ottawa. But with the news that a group of Winnipeg trekkers on their way to Ottawa had crossed into northern Ontario, his bluff was called. Accordingly, a law was quickly introduced prohibiting vehicles not licensed in Ontario from carrying passengers. ${ }^{54}$ The Toronto trek contingent was also informed that it would not be allowed to use trucks to transport marchers, except for three vehicles permitted to carry participants who became ill. ${ }^{55}$ Even after the trekkers left the city Hepburn attempted to dissuade them from their journey by offering free bus transportation home and emphasizing the availability of farm jobs. They refused all such opportunities. ${ }^{36}$ The policy reversals by Simpson and Hepburn illustrate that, while there was a mood of reform in Toronto, it was not strong enough to dominate. The Toronto trekkers, seeking support, received only sympathy. When they would nor quietly disappear, the underlying conservative nature of the Toronto environment began to assert itself. Respect for authority and law and order was a cornerstone of the philosophy being espoused by opponents of the trek, even those with more liberal reputations, like Hepburn and Simpson.

Thus, the Toronto trek contingent (officially called the On to Ortawa Trek) marched against the opposition of three levels of government. Particularly damaging to their cause was the provincial government's refusal to allow vehicles to carry trekkers. Undoubtedly the prospect of actually having to walk all the way to Ottawa reduced the number of participants. Originally the trek leadership predicted that 1,500 or more people in the Toronto area would march and 2,000 did take part in a police authorized gathering at Queen's Park that celebrated the 17 July beginning of the trek. A tag day was the first warning that there might be problems with support for the march: the collection garnered a disappointing $\$ 700$. When only 400 participated in the march, the fears were confirmed. An anonymous trekker wrote in the Globe that of those signed 
up to march, "at least a third of the addresses were fictitious; but the biggest blow has been the edict of Premier Hepburn regarding the use of trucks." "7

An advance party organized sleeping accommodation and food supplies, but conditions were still extremely difficult. Not far out of Toronto, desertions reduced the number of marchers to 300.58 Nevertheless, the remaining trekkers persevered. Included in this group was a women's section consisting of ten members, the youngest being fifteen years of age. Another woman, Communist Lil Himmelfarb, served as a march spokesperson. ${ }^{59}$

A highly organized system guided the marchers. The trek leadership enforced a strict code of discipline with expulsion being the ultimate penalty for any infraction. Nineteen rules were established, including prohibition of "obscene language or imoral [sic] conduct" and "frequent[ing] any saloon ... or ... partak[ing] of any intoxicating liquor." The marchers were also forbidden to communicate with the police or press unless permitted to by the General Trek Executive. ${ }^{60}$

The latter rule hints at the detrimental effect respective police forces had on the various trek movements in June and July 1935. The role of the Toronto Police was far less conspicuous than in the early 1930s, undoubtedly because civic and provincial authorities were less tolerant of police brucality. "1 In addition, two "highly placed officials" at Queen's Park secretly informed the RCMP that the "Provincial Government [did] not intend to take any action in regard to radical activities in [Ontario] prior to the forthcoming General Election." 62 Observation replaced obstruction: outside of Toronto the OPP, RCMP, and the Toronto Police shared the role of watchdog. Members of the latter force's "Red Squad" kept the contingent under surveillance as they moved east from the capital of Ontario. The OPP was less secretive: it had fifteen policemen on motorcycles accompanying the trekkers along their route. ${ }^{63}$

As the trekkers marched along the highway towards Kingston, the RCMP became more actively involved in surveillance. Observation of trek headquarters in Toronto 
by the Mounted Police was already underway. ${ }^{64}$ By the time the weary marchers reached Kingston, a Mounted Policeman had infiltrated their numbers. He recognized one fellow officer and believed there might have been still another. His report commented on the low morale of the marchers, caused in part by the inability of the rank-and-file to trust that their leaders were not RCMP agents. ${ }^{65}$ To combat espionage the trekkers were organized into units of twelve and encouraged to spy on each other in order to root out "stool pigeons." ${ }^{66}$

Not only had the police infiltrated the actual march but they also had informants in related organizations. Specifically, the Special Branch of the Toronto Police employed an "Operator," Mrs. Joe Paton, who was a member of various worker organizations and "the inner circle of the National Council of Unemployed." For $\$ 50.00$ a month, including "a special bonus, for any exceptionally good information, of $\$ 5.00$ or $\$ 10.00$," she supplied reliable intelligence on political and labour groups. In this case the Opp "obtained valuable information through her as to the plans, movements, etc., of the [Toronto trekkers]. ${ }^{n 7}$

Despite steep odds the marchers reached Kingston. Ottawa lay only a few days' walk away. To the approaching group of unemployed the city represented more than the capical of the nation. To them it exemplified the inequality, unfairness, and harshness of a political system which offered platitudes instead of policy, rhetoric in place of relief. The city would provide the opportunity to confront those held responsible for the hopelessness of their lives-the federal government.

The capital of Canada was not the sort of city likely to be a bastion of radicalism. It was a city where, according to Tom McEwen, "half the population was either on a Government 'payroll' of some sort-or hoping to get there." ${ }^{68}$ Politics is an industry that experiences few slumps. Ottawa would serve, however, as a microcosm of the entire Trek experience: protesters parading by the shadows of the Parliament buildings; extraordinary preparations on the part of the military and police to deal with what they perceived as a potential insurrection in their own backyard; 
and finally, conflict between various levels of government over the correct policy toward the Trek.

The citizens of Ottawa demonstrated little concern for the Trek during June 1935. The same can not be said for their mayor, P.J. Nolan, who expressed alarm right at the beginning of the On to Ottawa Trek in British Columbia. Nolan wired a complaint to his counterpart in Vancouver. ${ }^{69}$ He also attempted to intimidate any potential Trekkers by announcing on 7 June that several citizens had volunteered to form a vigilante squad to deal with any unwelcome visitors. Even the halting of the Trek in Regina did not end the mayor's machinations; he fretted about the possibility of trucks being used to transport the marchers into Oncario. In a letter to Premier Hepburn, Nolan asked that the province cooperate with the federal government to keep the Trekkers out "because we cannot shoo these men to another place or another Province after they arrive in our Province." The letrer further warned that the task of halting the Trek would only become more difficult since "there may be as many as three or four thousand and as they go through [Ontario] this number may swell to greater proportions." ${ }^{70}$

Only the presence of the Regina Trek delegation to meet with Bennett on 22 June managed to spark any public attention in Otcawa. The delegation and groups from Ontario and Quebec held a joint conference where after some disagreement an official call for a national trek to Ottawa was issued. ${ }^{\prime 1}$ The following evening the announcement was reiterated before a large crowd at Ottawa's Rialto Theatre. The meeting represented the only actual display of support for the Trek in the capical of Canada before the Regina Riot. ${ }^{72}$

The general apachy of the citizens of Ottawa toward the Trek continued even in the immediate aftermath of the Regina Riot. In contrast to several other Canadian cities, people did not demonstrate or raise an outcry in a city that had apparently settled in for a hot, humid summer. One hundred and fifty relief camp workers shattered this peaceful illusion when they went on strike, in part out of 
sympathy with the $\mathrm{BC}$ Trekkers, at the neighbouring Rockcliffe Royal Canadian Air Force (RCAF) relief camp. ${ }^{73}$

The authorities reacted swiftly. Those perceived to be the strike leaders were immediacely expelled from the camp. These expulsions, however, did not quell the disturbance. Two hundred RCAF and RCMP personnel peacefully ejected a further 138 men after they refused to work. ${ }^{74}$ Many of the Rockcliffe strikers would eventually join the Ontario trekkers marching to Ottawa, including one man who a few weeks later would recognize an undercover Mounted Policeman, disguised as a trekker, who had been at the Rockcliffe expulsions. ${ }^{75}$

The news in July that treks to Ottawa might begin from Winnipeg and various points in Ontario sparked Mayor Nolan to action. Those gathering in his province especially concerned him since they were a much more tangible threat. In a 12 July telegram to Hepburn he requested that the "ATTORNEY GENERAL ... TAKE SUCH STEPS AS MAY BE NECESSARY TO PREVENT THIIS MOVEMENT GAINING HEADWAY WITH CONSEQUENT POSSIBILITY OF SERIOUS DAMAGE TO PROPERTY AND PROBABLE LOSS OF LFE IF NOT CHECKED." Nolan also wired the mayors of Winnipeg, North Bay, and Toronto, warning that they would be held legally accountable for any damage or other expenses incurred should the marchers reach Ottawa." This pressure may have been partially responsible for the tougher line taken by Simpson and Hepburn toward the trekkers.

With marches for Ottawa underway from Winnipeg, preparing to leave from Toronto, and the potential of more starting from elsewhere in Ontario and Quebec, the nation's capical and its mayor reflected a siege mentality. A flurry of related activities occurred as the city prepared for the arrival of the trekkers. Another raid was launched against transients; Nolan floated the idea of forming a vigilante squad to supplement the city police; a conference was held berween various police forces to coordinate forces; the remaining Rockcliffe relief strikers were told to "work or leave town."78 
The OPP, RCMP, and Canadian military carried out their own preparations for the approaching trekkers. The opp cancelled summer leave for its members in the province's major industrial centres and Ottawa, conditional on the marchers reaching the national capital. The RCMP had already cancelled summer leave for all of its members at the beginning of July. ${ }^{79}$ Dealing with the trekkers occupied a great deal of the federal police force's time from midJuly to the end of August. Protecting government buildings and officials, especially Bennett, was their main concern. To aid in this goal the Mounted Police secured two buses for ten dollars on 2 August to transport ninety-six steelhelmeted and baton-equipped policemen from Rockcliffe to Ottawa in the event of disorder ${ }^{80}$ Additionally, the RCMP coordinated the searching of all rail cars bound for the capital to prevent trekkers from arriving by rail. ${ }^{81}$

Since it was charged with the city's defence the Canadian military also took a strong interest in the events in and around Ottawa. Many of those marching were also former members of the federal relief camps and consequently the particular responsibiliry of the Department of National Defence. On 13 July the District Officer Commanding (DOC) Military District 3 at Kingston was ordered secretly to ready an emergency military force composed of the regular army and, if necessary, the militia. The unit was designed to defend the Parliament buildings and other government installations should the marchers have arrived and attempted to storm them. The soldiers were to be held in readiness and be available at the request of the federal government. ${ }^{82}$

Despite the various plans to deal with the trekkers neither Ottawa businesses nor their mayor were reassured. Numerous store owners in the ciry's downtown acquired riot insurance in anticipation of trouble when the marchers would arrive. ${ }^{83}$ Nolan, in turn, sought even greater power to deal with the trek and its ramifications. On the advice of RCMP Commissioner MacBrien, he wrote to AttorneyGeneral Roebuck asking for the power to call in the Mounted Police. The request was coldly rebuffed, prompting 
Nolan to send his regrets "that apparently underlying this matter is the implication that because I am not a police officer I may not be trusted. ${ }^{\text {}} 4$

All of these preparations were for a few hundred trekkers. The first official group appeared in Ottawa on 17 July. Thircy people arrived on a freight train after having struck a relief camp near Pembroke, Ontario. Their leader predicted that the remainder of the 1,500 men would also walk out, but this did not happen although such rumours did encourage the Toronto trekkers as they trudged along mile after mile of the province's highways. Twelve days later, a contingent of twenty-three marchers arrived from Sudbury. ${ }^{85}$ As the main body from Toronto neared the capital the trekkers' main concern became accommodation and food. On 29 July, a delegation appealled to Ottawa's Board of Control for shelter and nourishment for 1,000 people; the request was rejected. ${ }^{86}$ Eventually privately owned land in an Ottawa park was provided for the marcher's accommodation. Food would be acquired through donations and the trekkers' own funds.

On 8 August, 478 individuals, including twenty-five women and forty-seven Ottawa-based trekkers, marched into the city. They paraded along Wellington Street, past Parliament Hill and on to the park where ramshackle accommodations were escablished. Hay and cardboard served as bedding for many. ${ }^{87}$

The authorities initially left the trekkers alone. Deliberately unobtrusive, the police attempted to prevent street and door-to-door solicications for food and funds. Demonstrations were also restricted. Although the trekkers threatened a parade, they backed down so as to ensure that no provocation would provide the police with an opportunity to crush their movement. ${ }^{83}$ The city attempted to use legal means to force the trekkers from the park, but the move failed because the marchers were sequestered on a private section of the park. ${ }^{89}$

Once in Ottawa the trekkers sought to gain the support and sympathy of ordinary citizens. To accomplish this cask they distributed manifestoes around the city. Included 
in the publication was a list of the marchers' grievances and an appeal to the citizenry for food and money. Perhaps taking into consideration the demographics of the intended readership, an attempt was made to link members of the working and middle classes in common cause against the Bennett government. ${ }^{90}$ In turn, many people responded by attending rallies and by offering food, bedding, clothing, and financial support. On the night of the Toronto marchers' arrival, thousands of people flocked to the park out of either genuine sympathy or simple curiosity. Demonstrations on 10,17 , and 18 August each attracted 2,000 people, fairly large numbers for a city with a conservative reputation. ${ }^{91}$ Gradually, however, the novelty of the event appeared to wear off. Attendance at meetings waned; donations declined. Perhaps a happier event, the annual Ottawa Exhibition, drew people's attention.

Rapidly the trekkers' chief concern became survival. Very little money remained, forcing the occasional missed meal. ${ }^{92}$ A 10 August meeting between trek leaders and Prime Minister Bennett illustrated the desperate situation. Instead of presenting a list of coherent demands, the delegation spent the time practically begging for food and shelter. Their pleas went unanswered as the meeting degenerated into a shouting match. ${ }^{93}$ Already having wasted their opportunity with Bennett, the trekkers now found it impossible even to meet with various political leaders; they were yesterday's news. Tired of the dwindling food supply and poor conditions, many trek participants deserted. Those who remained accumulated a supply of rocks to fend off any eviction attempts. One last plan to revitalize the trek's waning momentum lingered: the remaining faithful, with or without the permission of the city police, would parade to the Ottawa Exhibition grounds and take their case directly to thousands of fair goers. Not surprisingly, the Ottawa police warned that such a procession would not be allowed. Off-duty Mounted Policemen were recalled in anticipation of a clash. At the last minute, the trek leadership, undoubtedly realizing the hopelessness of their situation, backed down. Three days 
later on 23 August, after being refused free transportation back to Toronto, the march remnants set off on the long walk home. ${ }^{94}$ Over a month and a half after the Regina Riot, the On to Ottawa Trek finally limped to a conclusion. Only Ottawa's mayor was still entranced enough to offer a final comment. Nolan wrote a note to RCMP Commissioner J.H. MacBrien thanking the Mounted Police for their cooperation in confining "this movement to a very peaceful and ineffective expression of opinion [that] resulted in a complete failure as far as the unwarranted demands ... of the originators were concerned." MacBrien thanked the mayor for his compliment: "It was a great pleasure for us to work with you in an effort to reduce the seriousness of the On-to-Ottawa trek." 95

As elsewhere in Canada, the trek experience in Ottawa and Toronto was over. The march's significance in these cities was not based on numbers but rather on the attitudes it revealed. The CCF-CPC division was there for all to see. Also apparent was the paranoia of three levels of government as these bodies frantically attempted to prevent a revolution that was never intended, let alone realized. In subsequent years just the rumour of a trek would cause the Royal Canadian Mounted Police to generate several hundred pages of files.

Realizing the power of the state, the Trek leadership had no intention to provide the state with any justification for the crushing of their movement. Impediments put in place by the state dampened the enthusiasm for the trek, but the marchers themselves were never able to sway more than a handful of people to their cause. Many people were sympathetic to the plight of the trekkers; this feeling, however, never translated into active support and participation. Those interviewed on the streets of Toronto may have abhorred the violence in Regina, but they also realized that the ballot box, not the streets, would afford them the opportunity of registering their disapproval with the Bennett government; a few months after the Trek the electorate swept the Bennett government from office. Sympathetic politicians appeared to be more concerned 
with scoring political points than they were with the trekkers' cause. Premier Hepburn's liberal reputation would be shown to be hollow during the 1937 Oshawa General Motors strike.96

Historians of the Trek, perhaps extrapolating from the response in Western Canada to the marchers, have either ignored or misinterpreted the Trek's reception in Ontario. Perhaps viewed as a national phenomenon, the difference in support reflects the regional character of Canada and the uneven impact that the Great Depression had in different provinces. ${ }^{97}$ Historical writing on the Trek has yet to acknowledge that by the end of August 1935, a combination of government interference, the incompetence of the trek leadership, and general public indifference meant that the trek was an ineffective form of public protest in Ontario.

\section{NOTES}

* Special thanks to the editorial staff of Past Imperfect, the anonymous reviewers, Prof. W.A. Waiser, and Moira Harris for their helpful comments.

'To differentiate between the various treks, an upper case " $T$ " will be used to describe the men from British Columbia while a lower case " $t$ " will apply to all other trek movements.

2Victor Howard, "Citizen Support of the On-to-Ottawa Trek," in The Dirty Thirties in Prairie Canada, R.D. Francis and Herman Ganzevoort, eds. (Vancouver: Tantalus Research, 1980), 33-43.

${ }^{3}$ For more information on the British Columbia Trekkers see Victor Howard, "We were the salt of the earth!" The On-To-Ortawa Trek and the Regina Riot (Regina: Canadian Plains Research Center, 1985), and Lorne A. Brown, When Freedom Was Lost: The Unemployed, the Agitator, and the State (Montreal: Black Rose Books, 1987).

"Laurel Sefton MacDowell, "Canada's 'Gulag': Project \#51 Lac Seul (A Tale from the Great Depression)," Joumal of Canadian Studies 28 (2) (Summer 1993), 130-1.

'John Herd Thompson, with Allen Seager, Canada 1922-1939: Decades of Discord (Toronto: McClelland and Stewart, 1985), 280-1.

'James Struchers, No Fault of Their Own: Unemployed and the Canadian Welfare State, 1914-1941 (Toronto: University of Toronto Press, 1983), 79-82, 95-103.

'Brown, When Freedom was Lost, 103-46. 
8Jean Evans-Sheils and Ben Swankey, "Work and Wages:" A SemiDocumentary Account of the Life of Arthur H. (Slim) Evans (Vancouver: Trade Union Research Bureau, 1977), 147-8.

'Howard, "We were the salt of she earth!, "ix; Brown, When Freedom Was Lost, 175-6; Ronald Liversedge, Recollections of the On-to-Ortawa Trek, Victor Hoar, ed. (Toronto: McClelland and Stewart, 1973), $107-8$.

${ }^{10} \mathrm{How}$ ard, "We were the salt of the earth!, 170.

"Brown, When Freedom Was Lost, 203 and 197.

${ }^{12}$ lan Angus, Canadian Bolsheviks: The Early Years of the Communist Party of Canada (Montreal: Vanguard Publications, 1981), 274.

'13ita-Rose Betcherman, The Little Band: The Clashes between the Communists and the political and legal establishment in Canada, 1928-1932 (Ottawa: Denteau Publishers, n.d.), 59-85.

14Michiel Horn, "Keeping Canada 'Canadian': Anti-Communism and Canadianism in Toronto 1928-29," in Canada: An Historical Magazine 3 (1) (Sept. 1975): 36.

"Michiel Horn, "Free Speech Within the Law': the Letter of the Sixty-Eight Toronto Professors, 1931," Ontario History 72 (1) (March 1980): 27.

${ }^{16}$ S.M. Skebo, "Liberty and Authority: Civil Liberties in Toronto, 1929-1935," (MA thesis, University of British Columbia, 1968).

'Neil McKenty, Mitch Hepburn (Toronto: McClelland and Stewart, 1967), 49.

18 "The Mayoralty Result," Toronto Globe, 2 January 1935, 6. The Globe must really have been wondering what was happening to its world when Prime Minister Bennett made the first of his "New Deal" broadcasts the following day.

19 James Naylor. The New Democracy: Challenging the Social Order in Industrial Ontario, 1914-1925 (Toronto: University of Toronto Press, 1991), 22-3.

${ }^{20}$ Archives of Ontario (AO), Ontario Provincial Police (OPP) Records, E-96, File 1.6, Special Branch, Detective Department, Re. Ontario Hunger March, 19 June 1935, 1-2.

21"Ask Ottawa Invite 20 Hunger Marchers," Toronto Daily Star, 19 June 1935, 32: National Archives of Canada (NAC), Bennett Papers, Interview with the Joint Ontario and Quebec Delegation, 22 June 1935: 1-29 (479979-480008); "Minutes of Joint Meeting Held in Ottawa, June 22nd," in Evans-Shields and Swankey, "Work and Wages," 147-8.

22" Mobilizing Nationwide Campaign," The Worker, 2 July 1935, 1. ${ }^{23}$ Saskatchewan Archives Board (SAB), Regina Riot Inquiry Commission (RRIC), Exhibit 123, \#419, Arthur Evans to the Toronto Worker, 28 June 1935.

24"Arena Rally Friday Night in Toronto," The Worker, 2 July 1935, 1. 
2s"Presbytery Opposes Force in Dealing With Jobless," Toronto Daily Star, 26 June 1935, 29.

${ }^{26}$ University of British Columbia, Angus Maclnnis Collection, Box 30.2. Graharn Spry to Angus MacInnis, 25 June 1935, as cited in Skebo. "Liberty and Authority," 67.

${ }^{27}$ S.R. Hewitt, "We Are Sitting at the Edge of a Volcano': Winnipeg During the On-to-Ottawa Trek," Prairie Forum 19 (1) (Spring 1994): 54-5.

28"Law is Openly Defied By CCF Council," Toronto Globe, 1 July 1935. 11.

29"Ban On Strike Is Termed 'Un-British'," Toronto Globe, 2 July $1935,14$.

${ }^{30 "}$ C.C.F. Speakers Blame Bennett for Regina Riot," Toronto Globe, 3 July 1935, 10; "Right Under Magna Carta Must Be UpheldSimpson," Toronto Daily Star, 3 July 1935, 29.

31"Regina Riot 'Planned' to Aid Gov., Is Roebuck Charge," Toronto Globe, 4 July 1935. 1.

${ }^{32}$ Ibid., 1.

${ }^{33 "}$ "Sympathy Is Divided As Citizens Discuss Regina 'Hunger' Riot," Toronto Globe, 4 July 1935, 11.

${ }^{34}$ Toronto Daily Star. 5 July 1935, as cited in Skebo, "Liberty and Authority." 65.

${ }^{35}$ NAC, Bennett Papers, Toronto Dressmakers' Union to Bennett, 3 July 1935, 496211; Amalgamated Building Workers of Canada to Bennett, 4 July 1935, 496240; National Labour Council of Toronto to Bennett, 9 July 1935, 496713; Local Union No. 46 of the United Association of Journeymen Plumbers and Fitters, 5 July 1935. 496737; Rosedale Lodge No. 79 of the Brotherhood of Railway Carmen of America, 23 July 1935, 496758; 'Toronto Photo Engravers Union, Local No. 35, to Bennett, 25 July 1935, 496760; International Association of Firefighters, Local 411, to Bennett, 24 July 1935. 496763. The quote is from the last reference.

${ }^{36}$ Toronto Daily Star, 5 July 1935, as cited in Skebo, "Liberty and Authority," 65.

37"Rights Under Magna Carta Must Be Upheld—Simpson," Toronto Daily Star, 3 July 1935, 29.

38"Open Registration Booths For 'On-To-Ottawa' March," Toronto Daily Stnr, 6 July 1935, 19.

39"8,000 Join In Protest Against Regina Rioting, "New Commonwealth, 13 July 1935, 1.

tolbid., 3.

4)"Jobless Here Demand Probe," Toronto Globe, 6 July 1935, 1.

"2Trekker XXX, "Trekkers Led by Communists," Toronto Globe, 6 July 1935, 12.

43"C.C.F., Communists Clash at Meeting," Toronto Daily Star, 12 July 1935, 6 . 
4"Trekker Revolutionaries If Order Defied, Says Mayor," Toronto Daily Star, 15 July 1935, 2.

4s "Will Not Allow Public Appeal For Funds Here," Toronto Daily Star, 13 July 1935, 1-2.

46"Won't Stop Relief Of Hunger Trekkers," Toronto Daily Star 10 July 1935, 1; "Will Not Allow Public Appeal For Funds Here," Toronto Daily Star, 13 July 1935, 1-2.

47"Trekkers Revolutionaries If Order Defied, Says Mayor," Toronto Daily Star, 15 July 1935, 1-2.

43" Orders City Police To Aid Provincials," Toronto Daily Star, 15 July 1935. 1.

49" Council Refuses 11 To 4 to Hear Trek Spokesmen," Toronto Daily Star, 16 July 1935, 5; "Council Refuses To Hear Trekkers Plead For Tag Day," Toronto Globe, 16 July 1935, 9.

sou 14 Alleged Trekker-Taggers Are Arrested," Toronto Globe, 17 July 1935, 1 .

"AO, Premier Hepburn Papers, Box 185, Series 8. Hunger MarchHepburn General Correspondence, Handwritten Memo from McQuesten to Hepburn, 9 July 1935; "Ontario Won't Help Enforce Section 98 Hepburn Emphatic," Toronto Daily Star, 15 July 1935. 1; "Shaw Papers Signed Mandamus Dropped," Toronto Daily Star, 16 July 1935, 1.

32" Tightening Up On Hunger Army Hepburn Says," Toronto Daily Star, 17 July 1935, I, 3.

s'Ibid., 3.

stibid.

ss"Provinces Will Provide Buses Back To Toronto," Toronto Daily Star, 19 July 1935, 1-2; "Council Refuses To Hear Trekkers Plead For Tag Day," Toronto Globe, 16 July 1935. 9.

s6"Provinces Will Provide Buses Back to Toronto," Toronto Daily Star, 19 July 1935, I-2.

STTrekker XXX. "Trekkers' Enthusiasm Grows," Toronto Globe, 17 July 1935, 9-10.

saC, Department of National Defence Records, RG 24, Vol. 3029, File UER 87, Notes on Relief Camp Strikers and On-to-Ottawa Movement, 19 July 1935.

"Joan Sangster, Dreams of Equality: Women On The Canadian Left, 1920-1950 (Toronto: McClelland and Stewart, 1989), 141-2. ${ }^{6}$ Canada Security and Intelligence Service (CSIS), RCMP Records, Vol. 4, File H.V. 4, "Rules of the Trek," 6 August 1935, 1-2, (394-5).

"Betcherman, The Little Band, 214-5.

"Ibid., 4 July 1935, 1 (024).

${ }^{63}$ Trekker XXX. "Trekkers Fear Opposition To March," Toronto Globe, 24 July 1935, 10; Trekker XXX, "Expect Reinforcements At Trenton," Toronto Globe, 25 July 1935, 10. 
${ }^{4}$ CSIS, RCMP Records, Vol. 4, File H.V. 4, Report of R.W. Irvine, Toronto Detachment, 2 August 1935, 1(367).

os Ibid., Description of Harris, 4 August 1935, 3 (384); Report of Inspector F.A. Syms, 6 August 1935, 1 (369). Ironically, the RCMP discovered that one of the Toronto trek leaders, W.G. Harris, had been a Mountic before being drummed out of the Force.

${ }^{66}$ Toronto Daily Star, 22 July 1935, 19.

${ }^{67} \mathrm{AO}$, opp Records, E-96, File 1.2, Report re. Mrs. Joe Paton, 20 August 1935.

${ }^{68}$ Tom McEwen. The Forge Glows Red (Toronto: Progress Books, 1974), 164.

69"Believes Ottawa Ought To Share," Ottawa Journah 6 June 1935. 29.

${ }^{70}$ AO, Premier Hepburn Papers, Rg 3, Box 185, Series 8, P.J. Nolan to Hepburn, 20 June 1935.

71"Minutes of Joint Meeting Held in Ottawa, June 22nd," in EvansSheils and Swankey, "Work and Wages," 147-8.

$72^{2}$ Refusing To Take Further Promises Declares Leader," Ottawa Journah 24 June 1935, 13.

73"Minutes of Joint Meeting Held in Ottawa, June 22nd," in EvansSheils and Swankey, "Work and Wages," 147; "Relief Men Go On Strike At Rockcliffe," Ottawa Journah 8 July 1935, 1, 4. The strikers' specific demands included an eighty cent increase in pay, an eight hour working day, better food, and civilian rather than military control.

74"138 Men Are Ejected From Rockcliffe Relief Camp," Ottawa Joumah 10 July 1935, 1, 7; "Strikers Hold Meeting," Ottawa Joumah 15 July 1935, 7.

7"CSIS, RCMp Records, Vol. 5, File H.V. 4, Report of Constable M.J. Walsh, Div. A, 6 August 1935, 1-4 (396-9).

${ }^{76}$ AO, Premier Hepburn Papers, RG 3, Box 185, Series 8. Nolan to Hepburn, 12 July 1935.

77"Declares City Will Sue If Aid Given Strikers," Ottawa Journah 15 July 1935,7 .

78"Several Strikers Arrested In Raid," Ottawa Journah 11 July 1935, 2; "Montreal Men Won't Be Aided," Ottawa Journah 11 July 1935, 16; "Work Or Get Out, Is Mayor's Order," Ottawa Journah 12 July 1935. 127.

79u" "Provincial Police Leaves Cancelled," Ottawa Journah 15 July 1935 , 7: "No Summer Holidays For R.C.M.P. This Year, "Ottawa Evening Citizen, 3 July 1935, 1.

${ }^{80} \mathrm{CSIS}$, RCMP Records, Vol. 5, File H.V. 4, C.H. King to MacBrien, 9 August 1935, 1 (435); Report on Protection of the Prime Minister, 26 August 1935: 1 (547).

s!lbid., C.H. King to MacBrien, 2 August 1935, 1 (360). 
${ }^{82}$ NAC, DND Records, RG 24, File 359 Disturbances U.R. Camps, AG Memorandum to DOC 3, 13 July 1935, as cited in G.M. LeFresne, "The Royal Twenty Centers," (BA thesis, Royal Military College, 1962), 118-20.

83"Riot Insurance Taken Out By Local Merchants," Ottawa Evening Citizen, 8 August 1935, 2.

${ }^{84}$ CSIS, RCMP Records, Vol. 5, File H.V. 4, Nolan to Roebuck, 17 July 1935, 1 (365); Roebuck to Nolan, 1 August 1935, 1 (364); Nolan to Roebuck, 2 August 1935, 1 (362).

as" 30 Strikers From Petawa Reach Ottawa On Train," Ottawa Journal 17 July 1935, 1, 7; "Delegation Of Trekkers Will Ask City Help," Ottawa Evening Citizen, 29 July 1935, 1-2.

B6"Delegation Of Trekkers Will Ask City Help," Ottawa Evening Citizen, 29 July 1935, 1-2.

87"Trekkers Camp On Circus Grounds After Finishing Journey," Ottawa Evening Citizem 9 August 1935, 8.

"City Unable To Oust Trekkers From Camp," Ottawa Evening Citizen, 12 August 1935, 1-2; "Trekkers Vote Not To Parade Pending Parley," Ottawa Evening Citizen, 20 August 1935, 2; "Trekkers Again Decided Against Demonstrations," Ottawa Evening Citizen, 21 August 1935, 2.

89"City Unable To Oust Trekkers From Camp." Ottawa Evening Citizen, 12 August 1935, 1-2.

${ }^{90}$ CSIS, RCMP Records, Vol. 6, File H.V. 4, "We Demand a Hearing," 10 August 1935. 1 (453); "Statement of the 'On to Ottawa' Trekkers," 17 August 1935, 1-2 (486, 489); “Why a Demonstration?", n.d., 1 (491).

91"Trekkers Camp On Circus Grounds After Finishing Journey," Ottawa Evening Citizen, 9 August 1935, 8; CSIS, RCMP Records, Vol. 5 , File H.V. 4, Report from C.H. King to MacBrien, 9 August 1935, 12 (435-6); Ibid., Vol. 6, File H.V. 4, Report by Const. Styran on Strikers Marching to Ottawa, 12 August 1935, 2 (456); Report by King on Strikers, 12 August 1935, 2 (454); Report by King to MacBrien, 19 August 1935, 1-2 (486-7).

${ }_{92}$ lbid., Report of F.A. Syms, 19 August 1935, 1 (492); Report from C.H. King to MacBrien, 20 August 1935, 1-2 (499-500); "Report from Syms, 26 August 1935, 1 (548). The latter report is positively smug in its dismissal of the trek and particularly ingratiating towards its author's superiors.

93/bid., Report from C.H. King to MacBrien, 12 August 1935, 1-2 (453-4); "Bennett Refuses Trekkers Food and Shelter," Ottawa Evening Citizen, 10 August 1935, 1, 10.

"rCsIs, RCMP Records, Vol. 6, File H.V. 4, Report to C.H. King to MacBrien, 15 August 1935, 1-2 (469-70), 16 August 1935, 1-2 (479-80), 17 August 1935. 1 (482), 19 August 1935, 1-2 (486-7), 20 
August 1935, 1-2 (499-500); "Trekkers Vote Not To Parade Pending Parley," Ottawa Evening Citizen, 20 August 1935, 2; "Trekkers Again Decide Against Demonstration," Ottawa Evening Citizen, 21 August 1935, 3; CSIS, RCM? Records, Vol. 6, File H.V.4, C.H. King to MacBrien, 23 August 1935, 1-2 (537-8)

95Ibid., Nolan to MacBricn, 30 August 1935, 1 (558); MacBrien toNolan, 30 August 1935, I (561).

"Irving M. Abella, "Oshawa 1937," in On Strike: Six Key Labour Struggles in Canada, 1919-1949. Irving Abella, ed. (Toronto: James Lorimer, 1975), 93-128.

${ }^{97}$ The provinces with by far the two largest declines in per capita income between 1928-29 and 1933 were Saskatchewan (-72 percent) and Alberta (-6l percent). Ontario, with its tariff protected economy, was in the middle of the pack at ( -44 percent). Thompson, with Seager, Canada 1922-1939: Decades of Discord. 351. 